\title{
Biosorption effect of olive mill on heavy metal levels in serum
}

\section{and tissues of albino rats}

\author{
Omima I. Ali, Sahar M. Srour \\ Department of Biochemistry, Animal Health Research Institute, Dokki, Giza, Egypt.
}

\begin{abstract}
Two various kinds of olive mill solid residues (Crude and partly destoned) were used to investigate the adsorbing property of olive mill solid residues (OMSR) to heavy metals. 100 adult albino rats were classified into four groups. One group served as (-ve) control group (10 rats), received balanced ration and supplied tap water; in addition to three equal groups (each of 30 rats) received water polluted with $1 / 100 \mathrm{LD}_{50}$ of either lead, cadmium or copper at concentration levels( $107.2 \mathrm{mg} / \mathrm{L}, 8.8 \mathrm{mg} / \mathrm{L}$ or $58.4 \mathrm{mg} / \mathrm{L}$ respectively). Each main group was divided into 3 sub- groups, one (+ve) control and two experimental groups fed either $20 \%$ crude olive mill or $20 \%$ partly destoned olive mill. Polluted water administration extended for 1 month, meanwhile feeding $20 \%$ crude or partly destoned (OMSR) continued for further 30 days after cessation of polluted water as a withdrawal period. Samples of serum, muscle, liver and kidney were collected at one month of the experiment and at the end of the withdrawal period after one month. Level of metals were determined by atomic absorption spectrophotometer. Results indicate that crude olive mill exhibit higher adsorption capacities to $\mathrm{Pb}$, cd, and cu than partly destoned especially at withdrawal period. In conclusion, the main advantage of this process is the conversion of this waste product to a useful adsorbent material with low coast in minimizing the toxic hazard of environmental pollution with heavy metals.
\end{abstract}

Environmental pollution with heavy metals is considered to be one of the most important problems confronting human and animal health. Water pollution especially with heavy metals is a very critical environmental problem facing public health authorities.

The pollutants of concern include lead, cadmium and copper these toxic materials discharged into ecosystem are largely as a result of mining operations, refining ores, sludge disposal, fly ash from incinerators, metal plating or manufacture of electrical equipment, alloys and batteries (Ahalya et al., 2003).Presence of heavy metals in environment has a major threat due to their bio-accumulating tendency and toxicity (Thomas et al., 2008).

$\mathrm{Pb}$ and $\mathrm{cd}$ are toxic and non-essential metals, while $\mathrm{cu}$ is considered essential element, it occurs in drinking water from copper pipes as well as from additives designed to control algae growth. It becomes toxic when certain level is exceeded. Hence, it is necessary to remove these metals from industrial effluents before discharging aqueous waste into environment.

Biosorption of heavy metals is an innovative and alternative technology to remove these pollutants from aqueous solutions using inactive and dead biomasses such as algae, bacteria and agricultural and industrial wastes (Pagnanelli et al., 2002).

Biosorption has been proved as an excellent way to treat industrial waste effluents, offering significant advantages like low-cost, availability, profitability, easy of operation and efficiency (Ayhan, 2008).

Waste olive mill is the solid residue obtained from pressing the olives and is one of the most abundant agro-industrial wastes in the Mediterranean Region constituting a source of environmental problems caused by its accumulation and disposal. The waste olive mill is currently used as fertilizer, natural or transformed into a more stabilized amendment, as an additive to animal food and as a source of heat energy (Fernands et al., 2009). Recently some of these olive wastes in nature or processed forms have been tested as biosorbents for heavy metals in aqueous solution (Amro et al., 2002; Pagnanelli et al., 2002; Veglio et al., 2003).Conversion of this waste to a useful adsorbent contributes not only for the treatment of heavy metals contaminated environment but also to minimizing the solid wastes.

The present study was conducted to verify the efficiency of olive mill by-products (crude and partly) as heavy metal adsorbent materials 
when fed to rats exposed to metal polluted water with $(\mathrm{Pb}, \mathrm{cd}$ or $\mathrm{cu})$.

\section{Materials and methods}

Lead (pb). Lead acetate trihydrate was provided by Rieadel Dehaen, Hannover, Germany.

Cadmium (cd). Cadmium chloride was provided by M \&B laboratory chemicals "May \& B. LTD. Dagenham. England"

Copper (cu). Copper chloride was provided by Matrix Vet Preparation Co.

Crude olive mill. The residue of first extraction of the oil pressure from the olives.

Partly destoned olive mill: The residue from the partial separation of the stone from the pulp was provided by Osama Company. Animals and Experiment design: 100 adult albino rats with body weight ranged from (120-150 g) were used. Rats were classified into four groups; the first group of 10 rats fed balanced ration and supplied with tap water as $(-\mathrm{ve})$ control. In addition, 3 equal groups each of 30 rats all of them received $1 / 100 \mathrm{LD}_{50}$ of either lead, cadmium or copper according to MSDS(2006) in drinking water at concentrations $\quad(107.2,8.8$ or $58.4 \mathrm{mg} / \mathrm{L}$ respectively) daily for one month. Each group was subdivided into three subgroups of $(+\mathrm{ve})$ control and two experimental groups. ( $+\mathrm{ve})$ control. fed balanced ration contain no olive mill solid residue (OMSR). $1^{\text {st }}$ experimental group. fed ration consists of $(20 \%$ crude olive mill+ $80 \%$ balanced ration) according to (Rupic et al., 1999). $2^{\text {nd }}$ experimental group. received diet contain $(20 \%$ partly destoned olive mill $+80 \%$ balanced ration) according to (Rupic et al., 1999). All groups administered the polluted water for one month and the period of experiment extended for further one month after stoppage of polluted water administration as a withdrawal period.

Sampling. Five rats from each group were sacrificed after one month of drink's polluted water and at the end of withdrawal period (one month). Serum, muscle, liver and kidneys were taken from rats in all experimental groups.

Analysis of samples. Serum samples were prepared according to (Meret and Henkin, 1971). The muscle, liver and kidney samples were prepared and digested according to technique described by (Graig and Wayne, 1984). All samples were examined for measuring the levels of lead, cadmium and copper by using UNICAM 969 Atomic Absorption spectrophotometer.

Statistical analysis:

Parametric data were statistically analyzed using Analysis Of Variance (ANOVA) test and comparative of means were performed according to Duncan Multiple Range test for Comparative of Means according to (Duncan, 1955) using (SPSS 14, 2006).

\section{Results and Discussion}

Heavy metals (HM) make up one of the most important groups of pollutants, it accumulate in living things any time. HM are known to elicit a number of immunomodulatory effects ultimately leading to an enhanced susceptibility to microbial agent and the appearance of neoplastic diseases and autoimmune phenomena (El Hamed, et al., 2009; Liu et al., 2009; Zhang et al., 2009) The severities of these effects depend largely on the animal species, the routes, concentrations and duration of exposure (Martelli and Moulis, 2004).

Olive mill solid residue was used as heavy metal adsorbent material for its wide availability as agricultural waste and also for its cellulosic matrix, rich of potential metal binding active sites (Pagnanelli et al., 2002).

In this study, the concentrations of lead (pb) , cadmium (cd) and copper (cu) ppm in serum, muscle, liver and kidney of rats administered polluted water with1/100 $\mathrm{LD}_{50}$ of either pb,cd or $\mathrm{cu}$ equivalent to $(107.2 \mathrm{mg} / \mathrm{L} \mathrm{Pb}, 8.8 \mathrm{mg} / \mathrm{L} \mathrm{cd}$ or $58.4 \mathrm{mg} / \mathrm{L} \mathrm{cu}$ ) for one month and fed either $20 \%$ crude or partly destoned (OMSR) as a heavy metals adsorbent materials were assessed and also after cessations of polluted water administration for further one month as a withdrawal study.

The measured concentration levels of ( $\mathrm{pb}, \mathrm{cd}$ and $\mathrm{cu}$ ) in serum, muscle, liver and kidney of (ve) control, $(+v e)$ control and two experimental $\left(1^{\text {st }}\right.$ and $\left.2^{\text {nd }}\right)$ groups outlined in tables 1,2 and 3 . In the current work the concentration of (pb) at one month post-treatment in serum of (-ve) control group was significantly lower comparing with other groups at $\mathrm{p}<0.05$, while $\mathrm{Pb}$ values in muscles and kidneys of (+ve) control group recorded a significant increase $(p<0.05)$ in respective to other groups. Regarding to its level in liver $\left(1^{\text {st }}\right)$ group was significantly decrease $(\mathrm{p}<0.05)$ than $\left(2^{\text {nd }}\right)$ group (Table 1$)$.

Also, the present study revealed that at withdrawal period, concentrations of $\mathrm{Pb}$ in serum recorded no changes among groups. Regarding its levels in muscle, and kidney both experimental groups $\left(1^{\text {st }}\right.$ and $\left.2^{\text {nd }}\right)$ significantly decreased $(p<0.05)$ than $(+v e)$ control and increased than (-ve) control. Concerning estimation of $\mathrm{pb}$ in liver $\left(1^{\text {st }}\right)$ experimental group 
recorded significant decrease $\mathrm{p}<0.05$ than (2nd) group.

In this study the increment $\mathrm{pb}$ value in serum coincide with that reported by (Arrieta et al., 2005) in rats received different doses of lead acetate in drinking water. Moreover the increased $\mathrm{pb}$ levels in liver and kidney agreed with (Mestek et al., 1998) in rats administered polluted water with lead acetate. The recorded high bioconcentration of $\mathrm{pb}$ in serum and all examined organs resulted from pollution of water with lead may be due to that lead is taken up and stored faster than metabolized (Hipkins et al., 1998). Otherwise, the reported decrease in $\mathrm{pb}$ concentration in serum, muscle, liver and kidney of $\left(1^{\text {st }}\right.$ and $\left.2^{\text {nd }}\right)$ groups fed $20 \%$ crude or partly destond OMSR especially at withdrawal period may be related to the effect of OMSR which has cellulose matrix that interfere with the absorption of $\mathrm{HM}$, also it rich of potential metal binding active sites (Pagnanelli et al., 2002).

The results concerning cadmium (cd) levels (table, 2) revealed that after one month study (cd) concentration in (-ve) control group was significantly decrease at $p<0.05$ in serum and all examined organs of all groups. However, $(+v e)$ control showed significant elevation in cd levels at $\mathrm{p}<0.05$ in serum and examined organs comparing with all groups.

Meanwhile, at withdrawal period the level of (cd) in serum changed to become none significantly different among groups. Regarding to its value in muscle, $(+\mathrm{ve})$ control showed significantly level comparing with all groups. However $\left(1^{\text {st }}\right)$ experimental group recorded significant decrease $p<0.05$ than (2nd) group .Concerning its values in liver and kidneys level in, (-ve) control was significantly lower at $\mathrm{p}<0.05$, while $(+\mathrm{ve})$ control was significantly higher in respective to all groups.

Results of cd in this work were in agreement with (Brzoska et al., 2000; Brzoska et al., 2002) they noticed increased cd levels in liver and kidney of rats exposed to an aqueous solution of cadmium chloride.

The higher cd concentration in serum and all examined organs may be resulted due to consumption of polluted water $(8.8 \mathrm{mg} / \mathrm{L} \mathrm{cd})$ may be attributed to that cd has highly cumulative effect in different tissues especially liver and kidney (Jill et al., 2001).

On the other hand, the observed decrease of cd levels in serum and all examined organs of both experimental groups could be attributed to the high fibrous cellulose and pectin content of
OMSR there by preventing absorption of HM (Hamdi, 1993) or perhaps the fiber prevents adverse effects through action on digestive process or gut bacteria (Wang and Chen, 2009). It can be supposed that biosorption phenomenon occur by a general ion exchange mechanism for cd (Aziz et al., 2009).

Regarding to (Table ,3) it was obvious that at one month study its concentrat serum, muscle, liver and kidney showed significant lower levels at $\mathrm{p}<0.05$ of (cu) in (-ve) control as compared to all experimental groups.

Contrary (cu) levels showed significant elevation at $\mathrm{p}<0.05$ in serum and tested organs in $(+\mathrm{ve})$ control group comparing with other groups.However, at withdrawal study (cu) concentration in serum revealed non significant change among groups, while its levels in muscle, liver and kidney showed significant decrease at $\mathrm{p}<0.05$ in $(-\mathrm{ve})$ control and significant elevation in $(+\mathrm{ve})$ control. Also cu concentrations showed significant decrease in $\left(1^{\text {st }}\right)$ group as compared to $\left(2^{\text {nd }}\right)$ group. The data for cu were agreement with (Brzoska et al., 2002).

$\mathrm{Cu}$ concentration in experimenlal(+ev)group significantly increased than (-ve) control due to the increased level of (cu) in water, however the observed decrease in its level at one month after withdrowal of polluted water administration may be due to the adsorbed effect of OMSR to cu through an affinity series reflecting the hydrolytic properties of the metallic ions and it may combined with a specific complication reaction for copper (Pagnanelli et al., 2002). The obtained results for OMSR coincides with (Pagnanelli et al., 2002; Veglio et al., 2003) who investigate in their studies olive mill residues to heavy metal sorbent materials.

In This study we observed that OMSR by products have heavy metal adsorbing property, which able to remove HM. Also Morello et al., (2005) who reported that OMSR has antiradical and antioxidant activities due to mainly the presence of 3,4-dihydroxy moiety linked to aromatic ring. Moreover, the present results of this study indicate that crude OMSR exhibit higher adsorption capacities than partly destoned OMSR especially at withdrawal period; these results may be due to that partly destoned OMSR contains a small proportion of shell which cannot be separated from the pulp. For this reason it shows a lower fiber content 20$30 \%$ in comparison with crude olive mill content $35-50 \%$ (Nefazol, 1991).

In conclusion, the current study indicted that 
Table (1): Concentrations of lead (ppm) in serum and different organs of rats supplied polluted water with $(107.2 \mathrm{mg} / \mathrm{L} \mathrm{Pb})$ and fed either $20 \%$ crude or partly destoned OMSR for one month and after cessation of polluted water for anther one month $(n=5)$.

\begin{tabular}{|c|c|c|c|c|c|}
\hline & Organ & -Ve control & + Ve control & Crude $1^{\text {st }}$ group & Partly $2^{\text {nd }}$ group \\
\hline \multirow{4}{*}{$\begin{array}{l}\text { Post-treatment } \\
\text { study } 1 \text { month }\end{array}$} & Serum & $0.0009 \pm 0.0001 \mathrm{a}$ & $0.0017 \pm 0.0001 b$ & $0.0015 \pm 0.0001 b$ & $0.0016 \pm 0.0001 b$ \\
\hline & Muscle & $0.0047 \pm 0.0002 \mathrm{a}$ & $0.0098 \pm 0.0021 b$ & $0.0052 \pm 0.0001 \mathrm{a}$ & $0.0066 \pm 0.0001 \mathrm{a}$ \\
\hline & Liver & $0.0094 \pm 0.0004 \mathrm{a}$ & $0.080 \pm 0.0036 \mathrm{~b}$ & $0.0123 \pm 0.0004 \mathrm{ac}$ & $0.020 \pm 0.0010 \mathrm{ad}$ \\
\hline & Kidney & $0.0082 \pm 0.0004 \mathrm{a}$ & $0.010 \pm 0.0005 b$ & $0.0061 \pm 0.0018 \mathrm{a}$ & $0.0075 \pm 0.0014 \mathrm{a}$ \\
\hline \multirow{4}{*}{$\begin{array}{l}\text { Withdrawal } \\
\text { study 1month }\end{array}$} & Serum & $0.0008 \pm 0.0001$ & $0.0009 \pm 0.0001$ & $0.0007 \pm 0.0001$ & $0.0006 \pm 0.0001$ \\
\hline & Muscle & $0.0046 \pm 0.0003 \mathrm{a}$ & $0.00040 \pm 0.0005 b$ & $0.002 \pm 0.0007 \mathrm{c}$ & $0.0036 \pm 0.0010 \mathrm{c}$ \\
\hline & Liver & $0.009 \pm 0.0004 \mathrm{a}$ & $0.035 \pm 0.0016 \mathrm{~b}$ & $0.014 \pm 0.0013 \mathrm{c}$ & $0.020 \pm 0.0033 \mathrm{~d}$ \\
\hline & Kidney & $0.007 \pm 0.0004 \mathrm{a}$ & $0.0094 \pm 0.0004 b$ & $0.0086 \pm 0.0018 \mathrm{c}$ & $0.0087 \pm 0.0004 \mathrm{c}$ \\
\hline
\end{tabular}

a, b, c insignificantly difference between similar litter using Duncan Multiple Range test

Table (2): Concentrations of cadmium (ppm) in serum and different organs of rats supplied polluted water with $(8.8 \mathrm{mg} / \mathrm{L} \mathrm{cd})$ and fed either $20 \%$ crude or partly destoned OMSR for one month and after cessation of polluted water for anther one month $(n=5)$.

\begin{tabular}{|c|c|c|c|c|c|}
\hline & Organ & -Ve control & +Ve control & Crude $1^{\text {st }}$ group & Partly $2^{\text {nd }}$ group \\
\hline \multirow{4}{*}{$\begin{array}{l}\text { Post-treatment } \\
\text { study } 1 \text { month }\end{array}$} & Serum & $0.006 \pm 0.0013 \mathrm{a}$ & $0.018 \pm 0.0012 b$ & $0.014 \pm 0.0011 \mathrm{c}$ & $0.015 \pm 0.0013 \mathrm{c}$ \\
\hline & Muscle & $0.002 \pm 0.0001 \mathrm{a}$ & $0.008 \pm 0.0004 \mathrm{~b}$ & $0.004 \pm 0.0002 \mathrm{c}$ & $0.006 \pm 0.0003 \mathrm{c}$ \\
\hline & Liver & $0.003 \pm 0.0046 \mathrm{a}$ & $1.023 \pm 0.040 \mathrm{~b}$ & $0.65 \pm 0.002 \mathrm{c}$ & $0.835 \pm 0.003 c$ \\
\hline & Kidney & $0.004 \pm 0.0002 \mathrm{a}$ & $1.868 \pm 0.0812 b$ & $1.017 \pm 0.0424 \mathrm{c}$ & $1.321 \pm 0.0629 \mathrm{c}$ \\
\hline \multirow{4}{*}{$\begin{array}{l}\text { Withdrawal } \\
\text { study } 1 \text { month }\end{array}$} & Serum & $0.006 \pm 0.0003$ & $0.007 \pm 0.0003$ & $0.0051 \pm 0.0002$ & $0.0068 \pm 0.0003$ \\
\hline & Muscle & $0.002 \pm 0.0002 \mathrm{a}$ & $0.004 \pm 0.0002 b$ & $0.002 \pm 0.0001 \mathrm{ac}$ & $0.003 \pm 0.0002 \mathrm{ad}$ \\
\hline & Liver & $0.003 \pm 0.0014 \mathrm{a}$ & $0.023 \pm 0.0088 b$ & $0.012 \pm 0.0067 \mathrm{c}$ & $0.015 \pm 0.0079 \mathrm{c}$ \\
\hline & Kidney & $0.004 \pm 0.0002 \mathrm{a}$ & $0.063 \pm 0.0027 b$ & $0.048 \pm 0.0023 \mathrm{c}$ & $0.049 \pm 0.0020 \mathrm{c}$ \\
\hline
\end{tabular}

a, b, c insignificantly difference between similar litter using Duncan Multiple Range test

Table (3): Concentrations of copper (ppm) in serum and different organs of rats supplied polluted water with $(58.4 \mathrm{mg} / \mathrm{L} \mathrm{cu})$ and fed either $20 \%$ crude or partly destoned OMSR for one month and after cessation of polluted water for anther one month $(\mathrm{n}=5)$.

\begin{tabular}{llllll}
\hline & Organ & -Ve control & + Ve control & Crude 1 $^{\text {st }}$ group & Partly 2 $^{\text {nd }}$ group \\
\hline \multirow{3}{*}{ Post-treatment } & Serum & $0.98 \pm 0.03 \mathrm{a}$ & $1.913 \pm 0.21 \mathrm{~b}$ & $1.4 \pm 0.11 \mathrm{c}$ & $1.6 \pm 0.15 \mathrm{c}$ \\
study 1 month & Muscle & $9.75 \pm 1.61 \mathrm{a}$ & $39.63 \pm 3.84 \mathrm{~b}$ & $23.25 \pm 3.56 \mathrm{c}$ & $26.23 \pm 3.781 \mathrm{c}$ \\
& Liver & $20.3 \pm 3.31 \mathrm{a}$ & $81.71 \pm 6.312 \mathrm{~b}$ & $53.6 \pm 4.89 \mathrm{c}$ & $56.912 \pm 5.54 \mathrm{c}$ \\
& Kidney & $17.51 \pm 2.79 \mathrm{a}$ & $59.80 \pm 5.018 \mathrm{~b}$ & $31.64 \pm 3.98 \mathrm{c}$ & $34.35 \pm 3.61 \mathrm{c}$ \\
Withdrawal & Study & $0.801 \pm 0.09$ & $1.05 \pm 0.12$ & $0.901 \pm 0.15$ & $0.987 \pm 0.103$ \\
1 month & Muscle & $9.86 \pm 1.513 \mathrm{a}$ & $28.931 \pm 3.73 \mathrm{~b}$ & $11.78 \pm 2.01 \mathrm{c}$ & $14.96 \pm 1.908 \mathrm{~d}$ \\
& Liver & $21.3 \pm 3.614 \mathrm{a}$ & $67.32 \pm 5.1 \mathrm{~b}$ & $22.18 \pm 3.412 \mathrm{c}$ & $31.86 \pm 3.55 \mathrm{~d}$ \\
& Kidney & $16.51 \pm 2.81 \mathrm{a}$ & $49.56 \pm 4.38 \mathrm{~b}$ & $14.15 \pm 2.10 \mathrm{c}$ & $18.52 \pm 2.21 \mathrm{~d}$ \\
\hline
\end{tabular}

$\mathrm{a}, \mathrm{b}, \mathrm{c}$ insignificantly difference between similar litter using Duncan Multiple Range test.

olive mill solid residues was used as heavy metal adsorbent material for its wide availability as agricultural wastes and for its cellulosic matrix. Moreover the conversion of this waste to a useful adsorbent contributes not only for the treatment of heavy metals contaminated environment but also to minimizing the solid wastes.

\section{References}

Ahalya, N.; Ramachandra T.V. and Kanamadi, R. D. (2003): Biosorption of Heavy Metals. Res. J. Chem. Environ., 7 (4).

Amro, B.; Aburjal, T. and Al-khall, S. (2002): Anti oxidative and radical scavenging effects of olive mill extract. Fitoterapia, 73 (6): 456-461.
Arrieta, O.; Palencia, G.; Garcia-Arenas, G.; MoralesEspinosa, D.; Hernandez-pedro, N. and Sotelo. J. (2005): Prolong exposure to lead lowers the threshold of pentylenetetrazole- induced seizures in rats. Epilepsia, 46(10):1599-1602.

Aziz A.; Quali, M. S.; Elandalousis, El H.; De Menorval, L. C. and Lindheimer. M. (2009): Chemically modified olive stone: a low - coast sorbent for heavy metals and basic dyes removal from aqueous solutions. J. Hazard Mater., 163(1):441-447.

Ayhan, D.M. (2008): Heavy metal adsorption onto agrobased waste materials: A review. J. Hazard. Mater., 157(23):220-229.

Brzoska, M. M..; Moniuszko-Jakoniu. K. J.; Jurczuk. M.; Galazyn- Sidorczuk. M. and Rogalska. J. (2000): Effect of short - term ethanol administration on cadmium retention and bio- element metabolism in rats continuously 
exposed to cadmium. Alcohol and Alcoholism, 35 (5): 439445 .

Brzoska, M. M.; Moniuszko-Jakoniu, K. J. and Jurczuk, (2002): Cadmium turnover and changes of zinc and copper body status of rats exposed to cadmium and ethanol. Alcohol and Alcoholism, 37(3) : 213-21.

Duncan, D. B. (1955): "Multiple range test and multiple F tests." Biometrics, 11(1):1-42.

El Hamed, J. M, and Fatima H. (2009): Protective effects of selenium and zinc on cadmium toxicity in the liver of rat:effects on the oxidative stress. Ecotoxicol. Environ. Saf., 72(5):1559-1564.

Fernands, A.; Monteiro, S.; Pinto, F. and Mendes, B. (2009): Production of bisorbents from waste olive mill its adsorption characteristics for $\mathrm{Zn}^{2+}$ ion. Sustainability, 1,277-297.

Graig, D. S. and Wayne, C. (1984): Simple automated wet digestion of animal tissues for determination of seven elements by atomic absorption spectroscopy. Techn. Commun., 107:115.

Hamdi, M., (1993): Future prospects and constrains of olive mill wastewater use and treatments. Bioprocess Eng., 8:209-214.

Hipkins, K. L.; Materna, B. L.; Kosnett, M. J.; et al., (1998): Medical surveillance of the lead exposed worker. AAOHN J.,46: 330-339.

Jill, C. M.; Joseph, J. P. and Stephen, D. S. (2001): Principles and Methods of Toxicology. $4^{\text {th }}$ Ed edited by A.Wailace Hayes. Taylor and Francis, Philadelphia.

Liu, J. J.; Jamieson, S. M. and Jong, N. N. (2009): Neuronal expression of copper transporter 1 in rat dorsal root ganglia: association with platinum neurotoxicity. Cancer Chemother. Pharmacol., 64(4):847-856.

Martelli, A. and Moulis, J. M. (2004): "Zinc and cadmium specifically interfere with RNA binding activity of human iron regulatory protein 1."J. Inorg. Biochem., 98 (8):14131420 .

Meret, S. and Henkin, M. (1971): Simultaneous direct estimation by Atomic Absorption spectrophotometry of copper and zinc in serum, urine and cerebrospinal fluid. Clin. Chem., 17(5).

Mestek, O.; Deyl, Z.; Miksik, I.; Novotna, J.; Pfeifer, I. and Herget, J. (1998): Accumulation of lead in tissues after its administration in drinking water to laboratory rats. Physiol. Res., 47: 197- 202.

Morello, R.V.; Romero, M. P.; Motillva, M. J. and Heinonen, M. (2005): Antioxidant activity of olive pulp phenolic compounds of the barbequing cultivar.Agric Food Chem., 53(6):2002-2008.

MSDS (2006): Material Safety Data Sheet for lead acetate trihydrate, cadmium chloride anhydrous and copper chloride .http.//msds.ox.ac.uk.

Nefazol, A. (1991): Utilization of olive mill waste water as feed. Junta de An Andalucia, Sevilla (Spain). Direction General De Investigation Extension Agraries, 45: 137-155. Pagnanelli, F.; Toro, L. and Veglio, F. (2002): Olive mill solid residues as heavy metal sorbent material: a preliminary study. Waste Manag., 22 (8): 901-907.

Rupic, V.; Bozikov, V.; Bozac, R.; Vranesic, N. and Dikic M. (1999): Effect of feeding olive by- products on certain blood parameters and serum enzyme activities of fattening rabbits. Acta Vet. Hung., 47(1): 65-75.

SPSS 14 (2006): "Statistical Package for Social Science, SPSS for windows Release 14.0.0, 12June, 2006." Standard Version, Copyright SPSS Inc., 198902006, All Rights Reserved, Copyright SPSS Inc.

Thomas, A. J.; Niveta, J.; Joshi, H.C. and Shiv, P. (2008): Agricultural and agro-processing wastes as low cost adsorbents for metal removal from wastewater: A review. J. Sci. Indus. Res., 67:647-658.

Veglio, F.; Beolchini, F. and Prisciandaro, M. (2003): Sorption of copper by olive mill residues. Water Res., 37(20):4895-4903.

Wang, J. and Chen, C. (2009): Biosorbents for heavy metals and their future. Biotechnol Adv., 27(2): 195 -226.

Zhang, Y. M.; Liu, X. Z. and Lu, H. (2009): Lipid peroxidation and ultrastructural modification in brain after perinatal exposure to lead and/or cadmium in rat pups. Biomed. Environ. Sci., 22(5):423-429.

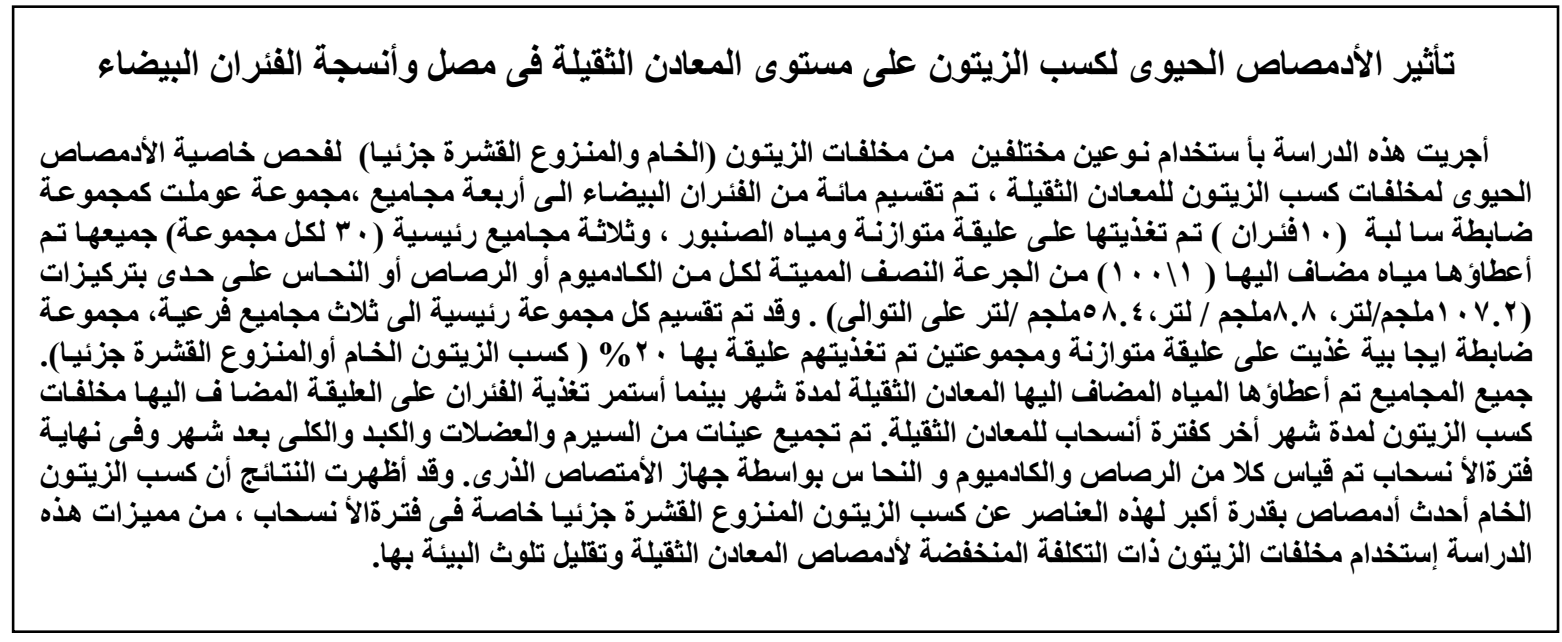

